\title{
Wages in the Theoretical Perspectives and Islam
}

\author{
JM. Muslimin ${ }^{1}$, Nurul Etika²
}

\begin{abstract}
Wages in The Theoretical Perspectives and Islam. Wages are a very basic value in business transactions. In wage agreements, the pattern and nature of the relationship between employers and workers can easily be identified. Unfair and exploitative wages occur because contracts are not open, lack transparency, and are not based on equality, understanding, and willingness. In the Marxist perspective, wages are always placed on suspicion of containing elements and relations of exploitation by the strong against the weak. In this context, transactions and wages are colored by capitalist elements and motives. Islam views wages as a gift from the Almighty which must be implemented in an affective-humanist manner. Although there are differences in roles between workers and employers, the answers to the material agreement are that of equality, openness, and willingness. On the other hand, at the same time, this principle is expected to make the character of work interconnected to make work relationships more conducive.
\end{abstract}

Keywords: Theory of wages, wages in Islam

Abstrak: Upah dalam Perspektif Teoritis dan Islam. Upah merupakan nilai yang sangat mendasar dalam transaksi bisnis. Dalam perjanjian upah, pola dan sifat hubungan antara pemberi kerja dan pekerja dapat dengan mudah didentifikasi. Upah yang tidak adil dan eksploitatif terjadi karena kontrak yang tidak terbuka, kurang transparan dan tidak dilandasi oleh kesetaraan, kesepahaman dan kemauan. Dalam perspektif Marxis, upah selalu dikaitkan dan dicurigai mengandung unsur dan relasi eksploitasi oleh yang kuat terhadap yang lemah. Dalam konteks ini, transaksi dan upah berpotensi diwarnai oleh elemen dan motif kapitalis. Islam memandang upah sebagai suatu anugerah Yang Maha Kuasa yang harus diimplementasikan secara afektif-humanis. Meskipun terdapat perbedaan peran antara pekerja dan pengusaha, keduanya terikat oleh kesepakatan material yang mementingkan kesetaraan, keterbukaan dan kemauan. Di sisi lain, pada saat yang sama, prinsip ini diharapkan dapat membuat karakter pekerjaan menjadi saling bergantung sehingga membuat hubungan kerja menjadi lebih kondusif.

Kata Kunci: Teori tentang upah, upah dalam Islam

\footnotetext{
${ }^{1,2}$ Sekolah Pascasarjana UIN Syarif Hidayatullah Jakarta, Jl. Kertamukti No. 5, Pisangan Barat, Ciputat Timur, Cireundeu, Tangerang Selatan, Banten 15419

E-mail: 1jm.muslimin@uinjkt.ac.id, 2nurul.etika@uinjkt.ac.id
} 


\section{Introduction}

In simple terms, wages can be defined as receipts for services or as compensation for performance spent on doing something. ${ }^{1}$ The wages, in law, are defined as the rights of workers/laborers that are received and expressed in the form of money, as compensation from the entrepreneur or employer to workers/laborers that are determined and paid according to a work agreement or statutory regulations, including allowances for workers/laborers and their families for a job or service that has been or will be performed. ${ }^{2}$ In terms of workers themselves, wages must be seen as a reward for the exchange of achievements between two parties, namely the worker and the employer, as rights and obligations received and given, or perhaps as a gift to workers who have done their job professionally and well. ${ }^{3}$

Some experts say that wages can also be used as a measure for the implementation of the principle of justice. This means that the wages are not only a matter of economic mathematics but are also related to standardization of performance and creativity which can be used as guidelines for salary increases, including work environment, existing infrastructure, duration/time limit, and so on. ${ }^{4}$ This standard is psychological in nature where justice can be an important measure against it.

This study will explain the differences in characteristics between general economic theory and Islamic law and their tendency to address wage issues. The following description will also discuss the payment of wages for jobs whose skills are not clear (syubhat) and how Islamic law views these wages.

The legal status of a case can be classified into 3 groups. First, in a case that is expressly stated as permissible by Syara', then the legal

${ }^{1}$ Departemen Pendidikan Nasional, Kamus Besar Bahasa Indonesia, 1st edn (Jakarta: Balai Pustaka, 1998), p. 994.

${ }^{2}$ Undang-Undang No. 13 Tahun 2003 tentang Ketenagakerjaan Ketentuan Umum Pasal 1 butir 30 .

${ }^{3}$ George T. Milcovich and Jerry M. Newman, Compensation (New York: Mc Graw, Hill, 2005), p. 5.

${ }^{4}$ Gary Dassler, Manajemen Sumber Daya (Jakarta:: Perenhallindo, 1998), p. 123. 
status is halal (lawful). Second, a case which is expressly prohibited by Shara', then the status is haram (forbidden). ${ }^{5}$ Third, in cases where the law is not clear or is still being debated by the jurists, then the legal status is Syubhat (vague/doubtful), for this case, it is recommended to be avoided as a form of wara' (piety/submission). ${ }^{6}$

Fiqh scholars break down the syubhat into three types. First, something that is lawful but doubtful. For example, a man doubts his divorced wife or whether she is a slave or has been freed. The case is, then, considered permissible until there is legal certainty. Second, a case that is known to be haram (unlawful) because it has been notified by someone else, but the truth of the person's notification is still doubted. For example: eating animal meat that is not known exactly how it was slaughtered, even though there are people who tell how the slaughtering process is, then the meat should be considered haram (unlawful) unless it can be ascertained that the method of slaughtering is according to the rules of Allah SWT. Third, in a case whose legal status is not known whether it is lawful or lawful then it is believed that the case is haram. ${ }^{7}$ If one of the last two possibilities above occurs, but there is no evidence to confirm it, then cases should be avoided. ${ }^{8}$ Because if in the next fact the case is proven to be haram, it means that he has freed himself from the haram act. On the other hand, if it is lawful, then he will be rewarded for his intention to keep himself from falling into a haram case. ${ }^{9}$

An individual who can do ijtihad (legal finding), and he does it so that he gets a legal conclusion about whether the case is lawful or not, must stick to the conclusion the beliefs in and is not justified in giving up his opinion just because he is afraid of being criticized by others. In other words, he must act according to his beliefs and

${ }^{5}$ God confirmed the halal for example in the QS. Al-Maidah: 5 and An-Nisa': 24. While the haram is stated as in QS. An-Nisa': 23 and Al-Maidah: 96.

${ }^{6}$ Yusuf al-Qardawi, Al-Halal Wa al-Haram Fi al-Islam, 15th edn (Beirut: al-Maktab alIslami, 1994), p. 12.

7 Yusuf al-Qardawi, Fikih Prioritas Sebuah Kajian Baru Berdasarkan Al-Qur'an Dan alSunnah, pp. 247-54.

${ }^{8}$ Ibn Daqiq al- 'Id, Sharh Al-Arbain Hadithan an-Nawawiyyah (Makkah: Dar Ibn Hazm, 1423), p. 31.

${ }^{9}$ Ahmad bin 'Ali bin Hajar al- 'Asqalani, Fath Al-Bari Bi Sharh al-Imam al-Bukhari, p. 341. 
dispel his doubts. If his ijtihad is wrong, he is forgiven, and the case is carried out following the law when he did so. This is following the qaidah: "al-yaqinu la yuzalu bi syak" (a belief cannot be dispelled with a doubt). This applies as long as the process of ijtihad is following what is known to the wider community. If, however, the ijtihad is weak, and the method is not known to the wider community, or if he does it only out of passion, then the case is considered syubhat, and it is advisable not to do the case. ${ }^{10}$

\section{Research methods}

The study was carried out using a normative economic law approach to describe the concept of wages as well as to compare the concept of wage transactions based on the Marxist theory and agreement in Islamic law. Through normative elaboration and comparison of these concepts, it is hoped that this research can be philosophically, juridically, and sociologically relevant to the current wage problems.

\section{Wages in Theoretical Perspectives}

Wages are seen as payments made concerning the employment relationship between workers and employers, or as a right that must be received or as a reward for work that has been done well. ${ }^{11}$ The current wage system has a new philosophy where wages are no longer seen as rewards for performance alone but as rewards to employees based on competence or individual contributions in their work. ${ }^{12}$ Wages are not an automatic process of which all submit to the weaknesses of others. ${ }^{13}$ Therefore, the wages in a job, always look at the expertise

${ }^{10}$ Yusuf al-Qardawi, Fikih Prioritas Sebuah Kajian Baru Berdasarkan Al-Qur'an Dan alSunnah (Jakarta: Robbani Press, 1996), pp. 247-54.

${ }^{11}$ George T. Milcovich and Jerry M. Newman, p. 5.

${ }^{12}$ Scott Snell and George Bohlander, Principles of Human Management, Fifteenth Edition (South-Western, Cengage Learning), p. 413.

${ }^{13}$ George Strauss and Leonard R.Sayles, Managemen Personalia: Segi Manusia Dalam Organisasi, Jilid II: Pengembangan Karyawan, Perlindungan Kerja, Pengembangan Manajemen Dan Organisasi, Serta Tantangan Personalia Dan Masa Depan (Jakarta: PT. Karya Unipress, 1991), p. 326. 
and knowledge. In other words, wages are often determined based on individual educational standards and years of experience (standardization of years of service). ${ }^{14}$

The nature of wages tends to fluctuate. ${ }^{15}$ Based on the economic situation that sometimes progresses and setbacks. Other opinions say that wage standardization must be more stable and constant. ${ }^{16}$

The wage system according to Karl Mark's theory is based on the theory of values and class conflict. According to him, an employer has a source of estimation from labor services or from the length of work time used to produce an item. The core of the company's activities, however, is in the hands of the workers. They are the first and foremost group to be more decisive. This includes determining the standardization of wages. Because in reality they rarely pay attention to their rights and roles. Unions, therefore are assumed to have absolute prerogative rights and must be able to make decisions regarding wages. Unfortunately, many entrepreneurs are reluctant to fulfill these rights. On the other hand, the employer feels like the owner of the means of production. In his hands, all decisions must be born. Workers are deemed to have fully followed the employer, including salary. ${ }^{17}$

There is also a wage theory that refers to the law of one price. In legal theory, one price used in the labor market has the same standard of work and should not be paid differently. But in reality, the standard of wages depends on the character of the entrepreneur. In conclusion, wages are largely determined by the agreement between the two. Usually,

${ }^{14}$ George Strauss and Leonard R.Sayles, p. 361.

15 Paul Devereux, 'The Cyclicality of Real Wages within Employer-Employee Matches', Industrial and Labor Relations Review, 54 (2001), 835-50 (p. 835) <https://doi.org/10.1177/ $001979390105400405>$.

${ }^{16}$ This statement is connected with union relations between countries that apply different wage systems. Countries that have stable or stable wages tend to benefit from a monetary union. Harris Dellas and George Tavlas, 'Wage Rigidity and Monetary Union', The Economic Journal, 115.506 (2005), 907-27 (p. 907) <https://doi.org/10.1111/j.1468-0297.2005.01024.x>.

${ }^{17}$ Machlup, Fritz, A History of Thought on Economic Integration (Columbia: Columbia University Press, 1977), pp. 32-36; Machlup, F, Methodology of Economics and Other Social Sciences (New York: Academic Press, 1987), pp. 65-69; Asian Drama: An Inquiry Into The Poverty of Nations (London: Allen Lane, The Penguin Press, 1968), pp. 12-18; Philip C. Newman, The Development of Economic Thought (New York: Prentice-Hall), p. 59. 
an agreement is reached because it is mediated and facilitated by a third party (regulator/government). ${ }^{18}$

Many factors increase workers' wages over time, not only because the workers are more productive, but also because firms maximize their profits by maintaining positive partnerships so that efficient calculations can be made. ${ }^{19}$ Among the several factors that make up wage differences are: First, different types of work..$^{20}$ Legal wage differentials have standards based on the quality of work, experience, and expertise. In a system that is increasingly concerned with human rights principles, two people who do the same job, cannot be paid different wages because of gender, race, or age. ${ }^{21}$ Second, the differences in the abilities, skills, and education of workers. Third, imperfect labor mobility. ${ }^{22}$ Here we can see a striking difference, between workers with complex managerial responsibilities, and technical workers, namely workers who are only oriented to simple things with limited skills. ${ }^{23}$

For workers, wages are very important. The amount of wages received is a reflection of measure and the value of a job. The number of wages earned by workers can also affect work performance, motivation, and job satisfaction. Therefore, if the wages are given to the workers accordingly and sufficiently, the workers will get job satisfaction and will be motivated to achieve a job goal. If the wages given are insufficient or not appropriate, however, it will have fatal consequences and can reduce work performance, motivation, and worker satisfaction. ${ }^{24}$

${ }^{18}$ Dale T. Mortensen, Wage Dispersion: Why Are Similar Workers Paid Differently? (London: Cambridge Massachusetts Institute of Technology, 2003), p. 9.

${ }^{19}$ John Sessions and Nikolaos Theodoropoulos, 'Tenure, Wage Profiles and Monitoring', Research in Labor Economics, 38 (2008), p. 148 <https://doi.org/10.1108/S0147-9121(2013)0000038004>.

${ }^{20}$ Sadono Sukirno, Pengantar Teori Ekonomi Mikro (Jakarta: PT. Rajawali Grafindo Persada, 1997), p. 310.

${ }^{21}$ Raymond A. Noe, et al, Fundamental of Human Resource Management (New York: McGraw - Hill, 2004), p. 347.

${ }^{22}$ In theory, there is the mobility of factors of production, including the mobility of labor. If indeed there is a difference in wages in the labor market, then workers will turn to the labor market with higher wages. Look at Payaman P. Simanjuntak, Pengantar Ekonomi Sumber Daya Manusia (Jakarta: LPFE UI, 1998), p. 38.

${ }^{23}$ Muhammad Abdul Mannan, Ekonomi Islam: Teori Dan Praktek,(Dasar-Dasar Ekonomi Islam) (Jakarta: Intermasa, 1992), p. 117.

${ }^{24}$ Wages in this case are also called compensation. Look at Manajemen Sumber Daya 
Above all, referring to Karl Marxian's theory, wages are very important and have many pervasive effects. If workers do not receive fair and adequate wages, it will not only affect purchasing power, but in the end, it will also affect the standard of living of workers, and, indirectly, all levels of society and the country's production. The fall in purchasing power over a very long time will be detrimental to producers of consumer goods. Thus, economically, the act of preventing workers from getting a fair share of their wages is tantamount to actions that will destroy the country's economy. ${ }^{25}$

The workers help themselves and their families to meet their needs. Wages do not depend on the amount of money received as payment for work, but on the amount of food, necessities, and various other necessities to which, according to the work habits of the workers, the money will be spent. Therefore, normal wages depend on the price of food and necessities that will support workers and their families. With an increase in prices and food needs, the workers 'normal wages will increase; Similarly, on the other hand, if the prices fall, the workers' normal wages will also go down. ${ }^{26}$ In short, dynamic wage standardization refers to ethical wage theory. According to this theory, the problem is not the number of wages a worker receives, but how far the wages earned will be able to cover all the necessities of life of workers and their families with standardized and humane sizes and classifications. ${ }^{27}$

Manusia (Bandung: Prospect, 2008), p. 76.

${ }^{25}$ Afzalur Rahman, Doktrin Ekonomi Islam, Jilid 2 (Yogyakarta: 1995), p. 362.

${ }^{26}$ The power of workers to help themselves and their families to complete the necessities of life. Wages do not depend on the amount of money received as payment for work, but on the amount of food, necessities, and various other needs which according to the worker's living habits, is where the money will be spent. Therefore, normal wages depend on the price of food, the right needs to support the lives of workers and their families. With an increase in food prices and necessities, even normal wages will increase, conversely if prices fall, then the normal wages of workers will fall. Look at David Ricardo, On The Principles of Political Economy and Taxation, (London: John Murray, Albemarle-Street, 1817), p. 58.

${ }^{27}$ Zaeni Asyhadie, Hukum Kerja: Hukum Ketenaga Kerjaan Bidang Hubungan Kerja (Jakarta: PT. Raja Grafindo Persada, 2007), p. 69. 


\section{Some Basic Rules in Islamic Law}

A rule is a principle, basis, or foundation, in a concrete or abstract sense. ${ }^{28}$ In his book entitled al-Asybah wa an-Naza ir, Imam as-Suyuti said that the basic rule is the law of kulli (wholeness) which includes its parts. ${ }^{29}$ The basic principles of fiqh are extracted from various kinds of fiqh provisions through inductive and deductive reasoning and then correlated with social reality. Some of the basic rules that can be applied to work agreements are:

(1) "The law of origin in all forms of mu'amalah is permissible unless there is a provision against it".

Every mu'amalah transaction (civil transaction) such as buying and selling, leasing, pawning, cooperation (mudaraba and musharakah), etc., is allowed unless it contains things that are strictly prohibited such as harming a party, fraud, gambling, and usury. ${ }^{30}$ This rule is closely related to freedom of contract. As long as the parties feel bound to each other in the framework of cooperation, innovation in the types of contracts and work agreements can vary widely according to the development of civilization and current trends in work. This diversity implies that the system and type of remuneration will also vary widely according to the diversity of contracts.

(2) "The legal origin of the contract is the willingness of both parties to transact, and the result is the validity of the contract". ${ }^{11}$

Willingness to transact is a principle. Therefore, a transaction is declared valid if there is a willingness from both parties. Conversely, an agreement becomes invalid if either party is coerced or cheated. For example, A buyer feels cheated and aggrieved by the seller, because the goods he bought are defective. Even though in the

${ }_{28}$ A. Dzajuli, Kaidah-Kaidah Fikih: Kaidah-Kaidah Hukum Islam Dalam Menyelesaikan Masalah-Masalah Yang Praktis (Jakarta: Kencana, 2011), p. 2.

29 Al-Imam Jalal ad-Din as-Suyuti as-Syafi'i, Al-Ashbah Wa an-Naza'ir Fi Qawa'id alFiqhiyyah (al-Qahirah: al-Maktab at-Thaqafi, 2007), p. 5.

${ }^{30}$ A. Dzajuli, p. 130.

${ }^{31}$ Abd al-Rahman ibn Abi Bakr al-Suyuti, Al-Ashbah Wa al-Nazair, Jami' al-Huquq alMuttafaqah Lijami' al-Muslimin (Islamicbook, 2010), p. 91. 
agreement there is already an explanation or guarantee that the goods purchased are fit for use and do not contain defects. ${ }^{32}$

(3) "Accepting something means accepting the consequences afterward." 33

Similar to the previous rule, but more generally, this principle alludes to the will. For example, Someone has signed a contract to buy a used car. That is, he agrees and accepts whatever the condition of the car is. Another example, if someone pawned goods to someone else, then the person who pawned them must accept the consequences that may arise during the installment period, such as damage and others. Remuneration in this context does not exist, but the benefits from the transactions obtained can be categorized as wages.

(4) "Everything harmful must be eliminated"

In the context of contract law, the hazard aspect can lead to Juridische Ausnahme (legal exception) in the form of the cancellation of the agreement, or more extreme, the elimination of the law. ${ }^{34}$ For example, there is a hire contract (ijarah), but the work can result in the loss of the worker's life, maybe the nature of the job does not pay attention to the protection and safety of workers, or because there is no adequate work infrastructure, then the contract can be canceled and the obligation/ remuneration rights automatically disappear.

(5) "Something which is prohibited from being taken is also prohibited from being given". 35

Everyone is prohibited from owning or receiving wages that do not belong to him or his right. Because it is forbidden to accept it, it is also forbidden to give it to others. Giving here includes gifts without rewards such as grants or gifts. Al-Imam al-Ghazali emphasized that in such cases the wage recipient must first ask, if the giver is not

${ }^{32}$ Ibid.

${ }^{33}$ Abd al-Rahman ibn Abi Bakr al-Suyuti, Al-Ashbah Wa al-Naza'ir, Jami' al-Huquq alMuttafaqah Lijami' al-Muslimin (Islamicbook, 2010), p. 91.

${ }^{34}$ Muhammad Tahir Mansoori, Kaidah-Kaidah Fiqh Keuangan Dan Transaksi Bisnis (Bogor: Ulul Albab Institute, 2010), p. 9.

${ }^{35}$ Al-Imam Jalal ad-Din as-Suyuti as-Syafi'i, p. 201. 
known, or is known as a loan shark, then the gift must be refused. However, if the giver is known then there is no need for questions (doubts). Examples of results of money laundering, ${ }^{36}$ usury, bribes, or speculation (gambling), which are used as gifts or wages to other people. The basis for this prohibition is the word of Allah SWT: "And work together in righteousness and piety, do not cooperate in sin and enmity." "According to al-Suyuti, this rule is almost the same as the rule: "Something that is forbidden to do is also prohibited from being prosecuted." 38

(6) "If it gathered what is lawful and unlawful, then the unlawful is strengthened"

Haram assets are divided into two parts, First, haram in substance and origin. Examples: dogs, pigs, or other people's belongings. Second, it is haram because of nature and how to get it. For example, assets obtained from unlawful acts such as gambling, usury, theft, confiscation, etc. ${ }^{39}$ Both types of assets above cannot be accepted and cannot be realized as wages. The agreement of the scholars on the ban was quoted by Ibn 'Abd al-Barr and others.

Al-Suyuti emphasized that if two covenants align between halal and haram, then the stronger law is the one that is haram. For example, buying and selling vinegar and wine, goat and pork, and so on, the law of buying and selling is haram. As the law of transactions is haram, the wages arising thereof are also haram. ${ }^{40}$

(7) "The right to obtain results arises from having to bear losses."

This rule analyzes the meaning of al-Kharaj, which is something that is produced either in the form of the benefit of an object such as a fruit-producing tree or a milk-producing animal, or work that

36 'Hukum Pencucian Uang Dan Menerimanya' < https://islam.nu.or.id/post/read/ 48419/ hukum- pencucian-uang-dan-menerimanya>.

${ }^{37}$ QS. Al-Maidah: 2

${ }^{38}$ Al-Imam Jalal ad-Din as-Suyuti as-Syafi'i, p. 201.

39 'Abbas Ahmad Muhammad al-Baz, Ahkam Al-Mal al-Haram (Dar an-Nafảis, 1998), p. 40.

${ }^{40}$ Abd al-Rahman ibn Abi Bakr al-Suyuti, p. 70. 
generates wages, all of which have risks as compensation. ${ }^{41}$

This rule has relevance to the Prophet's hadith which reads: "Your reward is based on the level of your effort". ${ }^{42}$ The conclusion of this hadith, if it is related to the rules of al-kharaj bi ad-damn, will produce a new rule, namely "the results (wages) of business following the number of costs incurred and benefits obtained according to the risk at hand" and also: "The pleasure is achieved according to the level of difficulty, and the difficulty faced is based on the level of pleasure to be achieved." ${ }^{\prime 3}$ This rule can also be interpreted as the number of wages depending on the level of complexity of the work. ${ }^{44}$

\section{"Wages and responsibilities are inseparable."}

This rule is widely used by the Hanafiyah school of scholars. ${ }^{45}$ An example of the application is as follows: Someone sends goods through a freight forwarder. The fee has been paid, and the goods will be delivered have been received by the company. During the delivery process, an accident occurred which resulted in the item being damaged. Here the expedition company cannot release its responsibility to compensate the sender for losses because the goods were damaged by the driver's negligence. So that he is still responsible for replacing with the same goods, if the goods are on the market, or paying the price of goods if the goods are not on the market. ${ }^{46}$ Likewise, if someone uses someone's vehicle without permission, then when there is damage to the vehicle, the user must provide compensation to the owner of the vehicle. ${ }^{47}$

${ }^{41}$ A. Djazuli, Kaidah-Kaidah Fikih: Kaidah-Kaidah Hukum Islam Dalam Menyelesaikan Masalah-Masalah Yang Praktis (Jakarta: Kencana Prenada Media Grup, 2006), p. 133.

${ }^{42}$ Abdul Mudjib, Kaidah-Kaidah Ilmu Fiqh (al-Qawaid al-Fiqhiyyah) (Jakarta: Kalam Mulia, 2001), p. 79.

${ }^{43}$ Umar Abdul al-Kamil, Al-Qawaid al-Fiqhiyyah al-Kubra Wa Atharuha Fi al-Mu'amalat al-Maliyah,' (unpublished Disertasi, Jami'ah al-Azhar as-Syarif, t.t), p. 189.

${ }^{44}$ Al-Imam 'Iz ad-Din ibn 'Abd as-Salam, Qawa'id al-Ahkam Fi Masalih al-Anam (Kairo: Dar al-Bayan al- 'Arabi, 2002), pp. 52-56.

${ }^{45}$ Ali Ahmad al-Nadwi, Al-Qawaid al-Fiqiyah (Beirut: Dar al-Qalam, 1998), p. 351.

46 'Majalah Ahkam Al- 'Adliyah, Pasal 416' <Majalah Ahkam al-'Adliyah, pasal 416, http:// legal.pipa.ps/files/server/ENG\%20Ottoman\%20Majalle\%20\%28Civil\%20Law29.pdf>.

${ }^{47}$ Muhammad Bakr Isma'il, Al-Qawaid al-Fiqhiyyah Bayn al-Isalah Wa at-Tawjih (t.t: Dar al-Manar), p. 209. 


\section{The Purposes of Work}

Work can be defined as all forms of the effort carried out by a person with his body or mind to obtain an appropriate reward, ${ }^{48}$ including types of work that require physical and mental exertion. Islam eliminates all class differences between humans and views charity as a responsibility that must be assumed by every individual according to his capacities and abilities. Work is considered valuable depending on the goal to meet all human needs and create a balance to reduce excessive attitudes. From an economic perspective, the work must be carried out with an agreement between the two parties which aims to realize principles of justice and responsibility. ${ }^{49}$

In Islamic teachings, humans are encouraged to seek their fortune through works. ${ }^{50}$ The Prophet Muhammad said, "practical training for Muslims must be provided so that they do not hesitate to work even though their income is small”. Islam prohibits mankind from begging or being a burden on the family and even the State. In Islamic teachings, humans are encouraged to seek their fortune, because everything in this world is directed to work. The Prophet Muhammad said, "practical training for Muslims must be provided so that they do not hesitate to work even though their income is small". Islam prohibits mankind from begging or being a burden on the family and even the State. ${ }^{51}$ Jobs recommended by Islam are jobs that are lawful, good, and productive, and bring benefits. Jobs recommended by Islam are jobs that are lawful, good, productive, and bring benefits. ${ }^{52}$

Imam al-Shaybani said that something that supports the obligatory

${ }^{48}$ Afzalur Rahman, p. 248.

${ }^{49}$ Fiqih Perburuhan, p. 15.

${ }^{50}$ The instruction to work in the Qur'an is explained in QS. Nuh: 19-20, an-Nisa': 97 and 100 .

${ }^{51}$ Rasulullah SAW kissed a friend's hand when he found out that the man's hand was rough and bruised because he worked using a sledgehammer, and he was very sympathetic to know it. The hadiths narrated from the fourth Caliph Ali r.a mentions that the Messenger of Allāh SA was hungry, and he worked so he could buy food for him. He worked cleaning the mud in a Jewish-owned garden outside Medina and obtained 17 dates for lifting 17 buckets of water. As a result, they eat the fruit together. (HR. Ibn Majah). See Afzalur Rahman, p. 248.

${ }^{52}$ Mustaq Ahmad, Etika Bisnis Dalam Islam (Jakarta: Pustaka al-Kautsar, 2003), p. 15. 
performance becomes obligatory. He further explained that carrying out a human obligation requires physical strength as a result of consuming food obtained from hard work. Therefore, work is an important element to carry out an obligation. From another perspective, work is an effort to activate economic activities, including the processes of production, consumption, and distribution. The end goal is to increase economic growth in a country. ${ }^{53}$

On the other hand, work is one indicator of the formation of ownership. To meet the increasing social needs one has to do extra work. The Marxists believe that under the auspices of their system, the individual who reaches the highest level of development will tend to work more and to the maximum. Therefore, in a social system, an individual is motivated to work harder because of his love for the system that was built by himself and not from the rewards promised to him. ${ }^{54}$

Islam establishes several principles in employment agreements, including:

(1) Freedom. Every person to carry out a work agreement including determining the contents of the agreement in all types of work as long as it does not contradict Islamic law.

(2) Equality. The two parties who enter into a work agreement have the same and equal position. So that it allows both parties to be responsible for carrying out their obligations

(3) Justice. Justice is the basis for elevating humanity. Syed Nawab Haider Naqvi believes that justice in the economy is a determining factor for the progress of the Islamic economic system compared to the economic systems of socialism and capitalism.

(4) Sincerity. The sincerity of each party who promised in an agreement is the life in every contract.

(5) Honesty and truth. If these two principles are not fulfilled, the legality

${ }^{33}$ Muhammad ibn Hasan al-Shaybani in al-Ikhtisan fi al-Rizq al-Mustatab, as quoted by Euis Amalia, Sejarah Pemikiran Ekonomi Islam Dari Masa Klasik Sampai Kontemporer (Jakarta: PUstaka Asatruss, 2005), p. 94.

${ }^{54}$ Muhammad H. Bahesti, Kepemilikan Dalam Islam (Jakarta: Pustaka Hidayah, 1992), p. 28. 
of an agreement will be damaged because one of the parties can betray the work agreement. Then the victim who is betrayed has the right to break the agreement before the end of the contract.

(6) Written. Writing or documents is very important in a work agreement, because if there is a dispute between the two parties, the article or documentation helps a problem, therefore the work agreement must be written. ${ }^{55}$

\section{Wages in Islam}

In fiqh mu'amalat, wages are included in the chapter of ijarah (hire agreement). According to Sayyid Sabiq, ijarah/ujrah comes from the word ajru which means al'iwad (substitution). With this understanding, al-thawab (a gift) can also be associated with wages. ${ }^{56}$

Judging from its linguistic terminology, the ijarah contract describes a reciprocal relationship between the parties, the workers, and the employers, as well as objects of it in the form of service and reciprocal compensation, including wages in return for a service. The ijarah contract is based on the value of manfaat (benefits), while the meaning of the benefit itself, as the object of ijarah, is abstract. Such results in many differences of opinion among the scholars regarding the legality of the ijarah contract. The Jumhur (majority) of scholars say that the ijarah contract is valid. Meanwhile, other scholars state that the ijarah contract is invalid because the object of the contract was abstract and contained elements of gharar (obscurity). ${ }^{57}$

The Ijarah contract is an agreement to utilize services. Therefore, if ijarah is directly related to a worker, it is the energy that is used; To contract workers, it must be determined in advance the type of work to be performed, time, wages, and labor. Ijarah strives for clarity in transaction honoraria, with evidence and features that can eliminate ambiguity.

\footnotetext{
55 Mustafa Dib al-Bugha, p. 184.

56 Sayyid Sabiq, Fiqih Sunnah, 13, VII (Bandung: al-Maarif, 1997).

57 Fiqih Perburuhan (Yogyakarta: Grafindo Litera Media, 2007), p. 45.
} 
In ijarah, the type of work must also be described very clearly so that nothing is blurred and that will result in the ijarah transaction becoming fasid (damaged). Compensation payments can be in the form of cash, it can also be in the form of assets or services or anything that can be valued at a price. $^{58}$

The giving of wages, as a reward for work, is permitted in Islam. ${ }^{59}$ The main principle of wages is fairness which lies in the clarity of the 'aqd (transaction) and the commitment of the parties. ${ }^{60} \mathrm{~A}$ worker is only entitled to his salary if he has carried out his job according to the agreement, because Muslims are very much bound by the conditions between them, except those that prohibit what is halal or otherwise justify what is haram. As long as the workers are paid in full, they must also fulfill their obligations. If they fulfill their obligations well, the employer should give something in addition to their salary as a gift or bonus. ${ }^{61}$

Wages themselves can be seen as services provided by workers as well as benefits provided by employers for work skills and services that are common in society. ${ }^{62}$ If the wages have been stated after the contract is agreed by both parties, the legal wages are the wages that have been

58 Taqyuddin al-Nabhani, p. 85.

59 Ahmad Abu Sarhan and 'Ali 'Abd Allah Abu Yahya, "Faskh al-Ijarah Bi al- 'Uzr Fi alFiqh al-Islami," (Ulum as-Shari'ah wa-al-Qanun, 2013), p. 112.

60 The hadith explaining the payment of this wage is from Abu Hurairah r.a., from the Prophet Muhammad. That he said: "Allah has said:" There are three types of people where I am their enemy on the Day of Judgment. First is the person who commits on my behalf (swears by my name), then he does not fulfill it. Second, the person who sells a free human being (not a slave), then seizes his money. Third, it is a person who hires a wage worker and employs him in full but does not pay his salary. (HR. al-Bukhari). Look at Aji Damanuri, 'Sistem Pengupahan Dalam Islam', 6.1 (2009), p. 108.

${ }^{61}$ Giving a gift or bonus to a worker when he works well, is based on the word of God in the an-Nisa letter, verse 173. Look at usuf al- Qaradawi, Peran Nilai Dan Moral Dalam Perekonomian Islam (Jakarta: Rabbani Press, 2001), p. 405.

62 The legal basis for wages in the Qur'an is among them QS. Al- Thalaq: 6, al- Zukhruf: 32, al-Qasas: 26, al-Baqarah: 233, al-Nisa': 74. In addition, Rasulullah also explained in his hadith, which means: "Give the wages to the worker before his sweat dries." Workers' wages are something that must be given on time. This message implies two things: first, as a worker, a person is required to be a hard worker, professional and serious. Second, wages are given on time following the level of work performed, a person may not be exploited by his employer for one job so that his rights are not given appropriately and fairly. See Amirul Nuruddin, Ekonomi Syariah Dalam Konteks Ekonomi Kerakyatan (Bandung: Ciptapustaka Media Perintis, Bandung), p. 23. 
mentioned; If the wages have not been stated at the time the contract was agreed, or there are problems during the work process, then the wages applied are wages that are under the work performed by the worker. In addition, wages are based on services provided by workers by taking into account the expertise and form of services. If the wages have been paid at the time of the contract, the wages charged are the wages that have been paid; whereas if the payment has not been made or there is a dispute over it, the wages that will be enforced are the wages that comply with certain standards. ${ }^{63}$

Wages can be divided into two forms; the first is al-ajr al-musamma or the wages mentioned at the time of the contract, and the second is al-ajr al-mithl or wages that are equivalent to those prevailing in the society. This second type of wage requires the seriousness and willingness of both parties to agree by looking at the aspect of equality between the work performed by workers and the wages to be paid. ${ }^{64}$

According to al-Mawardi, the basis for determining worker wages is an adequate standard, in the sense that at least it meets all the most basic needs of workers. ${ }^{65}$ There are several references in Islam for setting wages. First, wages are based on results. Second, wages are not based on the gender of the worker but on what he is doing. Third, in terms of time, the faster they complete is better. Fourth, from the perspective of justice, whoever works with the same result must be paid equally and professionally. Fifth, the minimum wage must meet the basic needs including food, clothing, and shelter. ${ }^{66}$

In the mechanism, wages can be increased or decreased before a job is carried out because the assets used in return for an agreed job can change, it can also go up or down as long as the work has not been done, as is done in the mudharabah contract. If there is a conflict

${ }^{63}$ Taqyuddin al-Nabhani, Membangun Sistem Ekonomi Alternatif: Perspektif Islam (Surabaya: Risalah Gusti, 1996), p. 84.

${ }^{64}$ Taqyuddin al-Nabhani, p. 84.

${ }^{65}$ Al- Mawardi, Al-Ahkam al-Sultaniyah (Kuwait: Dar Ibn Qutaybah, 1989), p. 205.

${ }^{66}$ Dep. Pengembangan Bisnis, Perdagangan dan Kewirausahaan Syariah Pengurus Pusat Masyarakat Ekonomi Syariah (MES), Etika Bisnis Islam (Jakarta: Gramata Publishing, 2011), p. 116. 
between the two parties who both swear by the oath, then the number of wages paid shall refer to the general salary and prevailing at that time (Ajr Mitsli). The amount of the salary is the same as the position of buying and selling, if any merchandise is damaged or defective, the price set by the seller will be the same as the basic price of the item. ${ }^{67}$

Islam recognizes that there are differences in the level of workers and jobs based on differences in abilities and talents. However, Islam does not recognize constant equality in the distribution of wealth because the progress of society develops according to their respective needs, resulting in differences in the distribution of wages. ${ }^{68}$

According to Jaribah al-Harithi, the measure of adequacy for workers' wages cannot be applied in the following cases, First, the difference in ability and expertise between a worker and another worker. With these requirements, there is no privilege for workers who have good skills and expertise. Second, the minimum wage limit must not be less than the minimum adequacy level of a worker so as not to cause bad things, for example, workers prefer to work in a place where the income is higher and that is easier to work with. Such will stop competition for worker productivity. Third, the equality of wages for a worker with other workers must be commensurate with a person's abilities and skills, the form of work, and others. If the salary given is equal, less, or more than the sufficiency level of a worker, then the minimum worker wage payment must be the same as the lowest level of adequacy. ${ }^{69}$

The payment of wages can be made in cash or not cash; it can also be in the form of assets or services, as long as it has a clear value because if it is not clear then it is considered invalid. ${ }^{70}$ Before starting a job, both parties must have an agreement in advance regarding the amount and mechanism of payment of wages. Islam allows employing

${ }^{67}$ Mustafa Dib al-Bugha, Fiqh Al-Mu'awadat (Damaskus: Dar al-Mustafa, 2009), p. 103.

${ }^{68}$ Muhammad Abdul Mannan, p. 117.

${ }^{69}$ Jaribah al-Harithi, Al-Figh al-Iqtisadi Li Amir al-Müminin 'Umar Ibn al-Khattab (Jeddah: Dar al-Andalus al-Khadra, 2003), p. 606.

${ }^{70}$ Mohammad Umar Chapra, The Future of Economics: An Islamic Perspective (The Islamic Foundation,), pp. 34-56; What Is Islamic Economics (Jeddah: Islamic Research and Training Institute, 1996), pp. 11-18. 
people without prior agreement on the payment of wages. ${ }^{71}$ This is in accordance with the ulama's fatwa which allows ordinary rent or wages that are not determined at the beginning of the agreement. If the benefits have been enjoyed, but the rental price is not determined, then the rental for the same benefit must follow the general rental rate in society. ${ }^{72}$ Wage payments can vary based on differences in employment. But the difference lies in the value of his services. not in terms of efforts. ${ }^{73}$

The labor force can be divided into 2, namely: manual labor and educated labor. ${ }^{74}$ The classification of workers based on the type of work depends on the quality of the workers themselves. To calculate the price of a worker for services, several considerations can be used, such as First, a healthy character and physique. Honest and responsible workers will work more diligently and assiduously. Likewise, workers who are healthy and strong are certainly better than workers who are weak and sick. Second, have good thinking power to create creativity and innovation in doing work. Third, have an adequate education and training background so that they can be more professional at work. ${ }^{75}$

\section{Wages in the Gray Area (Syubhat)}

All types of work performed by a person entitle him to receive compensation for his efforts following the promised party. In other words, something that is done with conditions, it can also be paid off with rewards. A lawful wage is a wage earned from work that contains benefits both between the promised party and the general public. On the other hand, haram wages are wages that contain the danger to aqidah (belief), morals, and civilization. In the context of wages in the gray

${ }^{71}$ Taqyuddin al-Nabhani, p. 90.

${ }^{72}$ Adiwarman A. Karim, Ekonomi Islam: Suatu Kajian Kontemporer (Jakarta: Gema Insani, 2018), p. 101.

${ }^{73}$ Taqyuddin al-Nabhani, p. 90.

${ }^{74}$ The existence of these unskilled laborers has been explained in the Koran among them QS: al-Qasas ayat 27, al-Kahfi ayat 77, al-Saba' ayat 10-11, Hud ayat 37-38. Likewise, the educated workforce regarding the events of the Prophet Joseph with the Egyptian king is described in QS. Yusuf ayat 54-56. Look atAfzalur Rahman, pp. 257-62.

${ }^{75}$ Fiqih Perburuhan, p. 62. 
area, it appears if the work promised is at a point between halal and haram or a mixture of the two; For example, a worker who receives wages for work to build a liquor factory or becomes a courier for the delivery of narcotics. In such cases, the question will arise whether the wages received by workers are lawful or haram because the work he does is considered haram.

The scholars' views differed on the status of wages in a matter of syubhat. Some of them argue that something that can be fulfilled with conditions can also be used as a basis for payment. However, if the case is still vague or doubtful, then the payment of wages, in that case, is also doubtful. As-Sadiq Abd Ar-Rahman al-Gharyani, gave an example of taking wages as a service to resolve disputes. Some scholars allow it because it is included in the category of ijarah. ${ }^{76}$ Others argue that if the case is in doubt then it must be abandoned because if it turns out to be haram (forbidden) it means that he has freed himself from doing forbidden acts. Conversely, if it turns out to be halal (lawful), then he will get an award because he has left something with the intention of not wanting to do haram. ${ }^{77}$

If a Muslim avoids any doubts about doing something that is not prohibited, then Islam considers it a good deed. Such caution gives Muslims more knowledge to think more about doing something. ${ }^{78}$ The famous hadith of the Prophet in this regard is: "The halal (lawful) is clear and the haram (unlawful) is also clear, and among them, there are doubtful things, which most people do not know. So, whoever shuns doubt, safeguards his religion and honor, but one who is involved in doubt, falls in Haram like a shepherd tending his animals near al-Hima (the land reserved for the king's animals); thus it is very likely that some of his animals will stray into it (al-Hima). Every king has a hima and the hima of Allah is what He forbids. "79

${ }^{76}$ As-Saddiq 'Abd ar-Rahman al-Gharyani, Fatawa Al-Mu'amalat as-Shari'ah (al-Qahirah: Dar as-Salam, 2003), p. 32.

${ }^{77}$ Ahmad bin 'Ali bin Hajar al-Asqalani, Fath Al-Bari Bi Sharh al-Imam al-Bukhari (Riyadh: Dar al-Ma'rifah2001), p. 341.

${ }^{78}$ Yusuf al-Qardawi, Al-Halal Wa al-Haram Fi al-Islam, p. 12.

${ }^{79}$ Imam al-Bukhari, Sahih Al-Bukhari (Beirut: Dar ibn Kathir, 2002), p. 494. 
Another hadith that emphasizes the same thing is: "Whoever keeps himself from doubt means he has saved his religion and honor, and whoever does not save his religion and honor, has committed an unlawful act" and the hadith: "Whoever falls into the territory of doubt has fallen into the territory of breaking the law". This above dalil form the basis for the suggestion of the majority of scholars to leave the syubhat case. People who do not fear Allah and do not care about syubhat cases will end up in cases of haram. Similarly, someone who often doing the syubhat will lose the essence of wara, and without realizing it he had fallen into forbidden affairs. ${ }^{80}$

\section{Conclusion}

Islam teaches mankind that in carrying out work transactions (ijarah) it is necessary to pay attention to several main principles, which include: the promised work must be good and lawful (not prohibited by Syara'), based on mutual desire and sincerity, and have clarity about the duration of work, the number of wages and other mutually agreed provisions. In a work agreement, no party may be harmed both to the worker and the employer. Paying worker's wages correctly and perfectly is part of the effort to fulfill the work contract. Workers may break the agreement if they feel they are being treated unfairly in determining wages; On the other hand, the employer can dismiss the worker if later it is proven that the worker is incompetent or has committed actions that deviate from the work agreement.

\section{Bibliography}

A. Djazuli, Kaidah-Kaidah Fikih: Kaidah-Kaidah Hukum Islam Dalam Menyelesaikan Masalah-Masalah Yang Praktis (Jakarta: Kencana Prenada Media Grup, 2006)

A. Dzajuli, Kaidah-Kaidah Fikih: Kaidah-Kaidah Hukum Islam Dalam Menyelesaikan Masalah-Masalah Yang Praktis (Jakarta: Kencana, 2011)

${ }^{80}$ Ibn Daqiq al- 'Id, Sharh Al-Arbain Hadithan an-Nawawiyyah, pp. 26-31. 
'Abbas Ahmad Muhammad al-Baz, Ahkam Al-Mal al-Haram (Dar anNafa'is, 1998)

Abd al-Rahman ibn Abi Bakr al-Suyuti, Al-Ashbah Wa al-Nazäir, Jami' al-Huquq al-Muttafaqah Lijami' al-Muslimin (Islamicbook, 2010)

Abdul Mudjib, Kaidah-Kaidah Ilmu Fiqh (al-Qawaid al-Fiqhiyyah) (Jakarta: Kalam Mulia, 2001)

Adiwarman A. Karim, Ekonomi Islam: Suatu Kajian Kontemporer (Jakarta: Gema Insani, 2018)

Afzalur Rahman, Doktrin Ekonomi Islam, Jilid 2 (Yogyakarta: 1995)

Ahmad Abu Sarhan and 'Ali 'Abd Allah Abu Yahya, "Faskh al-Ijarah Bi al- 'Uzr Fi al-Figh al-Islami," (Ulum as-Shari' ah wa-al-Qanun, 2013)

Ahmad bin 'Ali bin Hajar al-Asqalani, Fath Al-Bari Bi Sharh al-Imam al-Bukhari (Riyadh: Dar al-Ma'rifah2001)

Aji Damanuri, 'Sistem Pengupahan Dalam Islam', 6.1 (2009)

Al- Mawardi, Al-Ahkam al-Sultaniyah (Kuwait: Dar Ibn Qutaybah, 1989) Ali Ahmad al-Nadwi, Al-Qawaid al-Fiqiyah (Beirut: Dar al-Qalam, 1998) Al-Imam 'Iz ad-Din ibn 'Abd as-Salam, Qawaid al-Ahkam Fi Masalih al-Anam (Kairo: Dar al-Bayan al- 'Arabi, 2002)

Al-Imam Jalal ad-Din as-Suyuti as-Syafi'i, Al-Ashbah Wa an-Nazäir Fi Qawaid al-Fiqhiyyah (al-Qahirah: al-Maktab at-Thaqafi, 2007)

Amirul Nuruddin, Ekonomi Syariah Dalam Konteks Ekonomi Kerakyatan (Bandung: Ciptapustaka Media Perintis, Bandung)

Asian Drama: An Inqury Into The Poverty of Nations (London: Allen Lane, The Penguin Press, 1968)

As-Saddiq 'Abd ar-Rahman al-Gharyani, Fatawa Al-Mu'amalat as-Shari 'ah (al-Qahirah: Dar as-Salam, 2003)

Dale T. Mortensen, Wage Dispersion: Why Are Similar Workes Paid Differently? (London: Cambrige Massachusetts Institute of Technology, 2003)

David Ricardo, On The Principles of Political Economy and Taxation, (London: John Murray, Albemarle-Street, 1817)

Dellas, Harris, and George Tavlas, 'Wage Rigidity and Monetary Union', 
The Economic Journal, 115.506 (2005), 907-27 <https://doi.org/10 $.1111 /$ j.1468-0297.2005.01024.x>

Departemen Pendidikan Nasional, Kamus Besar Bahasa Indonesia, 1st edn (Jakarta: Balai Pustaka, 1998)

Dep.Pengembangan Bisnis, Perdagangan dan Kewirausahaan Syariah Pengurus Pusat Masyarakat Ekonomi Syariah (MES), Etika Bisnis Islam (Jakarta: Gramata Publishing, 2011)

Devereux, Paul, 'The Cyclicality of Real Wages within Employer-Employee Matches', Industrial and Labor Relations Review, 54 (2001), 835-50 <https://doi.org/10.1177/001979390105400405>

Euis Amalia, Sejarah Pemikiran Ekonomi Islam Dari Masa Klasik Sampai Kontemporer (Jakarta: PUstaka Asatruss, 2005)

Fiqih Perburuhan (Yogyakarta: Grafindo Litera Media, 2007)

Gary Dassler, Manajemen Sumber Daya (Jakarta:: Perenhallindo, 1998) George Strauss and Leonard R.Sayles, Managemen Personalia: Segi Manusia Dalam Organisasi, Jilid II: Pengembangan Karyawan, Perlindungan Kerja, Pengembangan Manajemen Dan Organisasi, Serta Tantangan Personalia Dan Masa Depan (Jakarta: PT. Karya Unipress, 1991)

George T. Milcovich and Jerry M. Newman, Compensation (New York: Mc Graw, Hill, 2005)

'Hukum Pencucian Uang Dan Menerimanya' < https://islam.nu.or.id/ post/read/48419/hukum-pencucian-uang-dan-menerimanya>

Ibn Daqiq al- 'Id, Sharh Al-Arba'in Hadithan an-Nawawiyyah (Makkah: Dar Ibn Hazm, 1423)

Imam al-Bukhari, Sahih Al-Bukhari (Beirut: Dar ibn Kathir, 2002)

Imam Taj ad-Din 'Abd al-Wahhab bin Aliyy ibn 'Abd al-Kafi as-Subki, Al-Ashbah Wa an-Naza'ir, 1 (Bairut: Dar al-Kutub 'Ilmiyah, 1991) Jaribah al-Harithi, Al-Figh al-Iqtisadi Li Amir al-Mu'minin 'Umar Ibn al-Khattab (Jeddah: Dar al-Andalus al-Khadra, 2003)

Look at Sayyid Sabiq, Fiqih Sunnah, 13, VII (Bandung: al-Maarif, 1997) Machlup, F, Methodology of Economics and Other Social Sciences (New York: Academic Press, 1987) 
Machlup, Fritz, A History of Thought on Economic Integration (Columbia: Columbia University Press, 1977)

'Majalah Ahkam Al- 'Adliyah, Pasal 416' <Majalah Ahkam al- 'Adliyah, pasal 416, http://legal.pipa.ps/files/server/ENG\%20Ottoman\%20 Majalle\%20\%28Civil\%20Law29.pdf>

Manajemen Sumber Daya Manusia (Bandung: Prospect, 2008)

Mohammad Umar Chapra, The Future of Economics: An Islamic Perspective (The Islamic Foundation,)

Muhammad Abdul Mannan, Ekonomi Islam: Teori Dan Praktek,(DasarDasar Ekonomi Islam) (Jakarta: Intermasa, 1992)

Muhammad Bakr Isma’il, Al-Qawaid al-Fiqhiyyah Bayn al-Isalah Wa atTawjih (t.t: Dar al-Manar)

Muhammad H. Bahesti, Kepemilikan Dalam Islam (Jakarta: Pustaka Hidayah, 1992)

Muhammad Tahir Mansoori, Kaidah-Kaidah Figh Keuangan Dan Transaksi Bisnis (Bogor: Ulul Albab Institute, 2010)

Mustafa Dib al-Bugha, Figh Al-Mu'awadat (Damaskus: Dar al-Mustafa, 2009)

Mustaq Ahmad, Etika Bisnis Dalam Islam (Jakarta: Pustaka al-Kautsar, 2003)

Payaman P. Simanjuntak, Pengantar Ekonomi Sumber Daya Manusia (Jakarta: LPFE UI, 1998)

Philip C. Newman, The Development of Economic Thought (New York: Prentice Hall)

Raymond A. Noe, et al, Fundamental of Human Resource Management (New York: McGraw - Hill, 2004)

Sadono Sukirno, Pengantar Teori Ekonomi Mikro (Jakarta: PT. Rajawali Grafindo Persada, 1997)

Scott Snell and George Bohlander, Perinciples Og Human Management, Fifteenth Edition (South-Western, Cengage Learning)

Sessions, John, and Nikolaos Theodoropoulos, 'Tenure, Wage Profiles and Monitoring', Research in Labor Economics, 38 (2008) <https:// doi.org/10.1108/S0147-9121(2013)0000038004> 
Syaikh Islam Ibnu Taymiyah, Majmu’ Fatawa (2004: Mamlakah al'Arabiyah as-Su'udiyah,)

Taqyuddin al-Nabhani, Membangun Sistem Ekonomi Alternatif: Perspektif Islam (Surabaya: Risalah Gusti, 1996)

Umar Abdul al-Kamil, 'Al-Qawa'id al-Fiqhiyyah al-Kubra Wa Atharuha Fi al-Mu'amalat al-Maliyah,' (unpublished Disertasi, Jami'ah al-Azhar as-Syarif, t.t)

What Is Islamic Economics (Jeddah: Islamic Research and Training Institute, 1996)

Yusuf al- Qaradawi, Peran Nilai Dan Moral Dalam Perekonomian Islam (Jakarta: Rabbani Press, 2001)

Yusuf al-Qardawi, Al-Halal Wa al-Haram Fi al-Islam, 15th edn (Beirut: al-Maktab al-Islami, 1994)

—, Fikih Prioritas Sebuah Kajian Baru Berdasarkan Al-Qur'an Dan al-Sunnah (Jakarta: Robbani Press, 1996)

Zaeni Asyhadie, Hukum Kerja: Hukum Ketenaga Kerjaan Bidang Hubungan Kerja (Jakarta: PT. Raja Grafindo Persada, 2007) 